\title{
Productivity of photosynthesis in Scots pine (Pinus silvestris L.) seedlings grown under various soil moisture conditions*
}

W. ŻELAWSKI, J. KUCHARSKA, A. LOTOCKI

The effect of transient water stress on the photosynthetic and respiratory activity of plants has been studied by numerous authors (see literature reviews: St ocker 1956; Pisek 1960; Larcher 1965; Rutter 1966, Kozlowski and Keller 1966) but relatively little is known on the influence of permanent water deficiency on the gas exchange in leaves. In particular those plant species which naturally occur within a wide range of soil moisture conditions, like Pinus silvestris, are interesting in this respect. Investigation of the adaptability of plants growing under various water supply conditions may help to explain the causes of their different growth and productivity.

The present study was carried out with seedlings in the second year of growth. It aimed at estimating the influence of different soil moisture pretreatments on growth, dry matter distribution within plant organs, photosynthesis, respiration and transpiration of the new developing shoot.

Plants from three different seed sources of Polish origin were used, like in our previous works (Żelawski and Góral 1966; Żelawski and Kinelska 1967; Żelawski, Kinelska and Łotocki 1968). However, as no distinct interaction was found between provenance and treatment, it was decided to present and discuss all data jointly for the whole population of pine without making distinctions between the different strains.

\section{MATERIAL AND METHODS}

Seed was sown at the end of April 1966 in standard pots $(21 \mathrm{~cm}$ in diameter and $27 \mathrm{~cm}$ high) containing $11.2 \mathrm{~kg}$ of loamy-sandy forest soil. The different water regimes were maintained by watering the pots to a constant weight once a day or every second day in dependence on the evaporation conditions. Water was always added at the bottom of the pot so that it reached the root layer only by capillary ascension. The amount of water to be maintained per pot was calculated for three levels of capillary capacity: 40, 60 and $80 \%$ corresponding to $10.7,16.0$, and $21.4 \%$ of absolute water content (in relation to dry weight of the soil). It is obvious that with such a procedure the water potential of the soil is not uniform throughout

\footnotetext{
* This work was carried out with the financial assistance of the U.S. Department of Agriculture.
} 
the whole root medium and cannot be strictly defined; hence it seems to be more justified to speak only of the relative differences in soil moisture and to describe the experimental treatments as "dry", "moderate" and "wet", respectively, instead of giving less reliable data on water tension.

The plants grew out of doors (under a wire net only) and were wheeled for nights and rainy periods under glass. At the end of the first vegetation season the initial number of plants (17) was reduced to 10 . Two average plants from each pot were taken for growth characterization and for determination of the dry matter accumulated in their aerial parts. Altogether 96 plants from each variant of soil moisture conditions were harvested at that time. The rest (144 pots) overwintered under glass in an unheated greenhouse under conditions close to natural.

In spring 1967 when shooting had begun, gas exchange measurements were started with plants brought from the greenhouse into the laboratory.

Photosynthesis was measured in terms of rate of change in $\mathrm{CO}_{2}$ concentration from 350 to $300 \mathrm{ppm}$ in a closed circuit system of an infrared $\mathrm{CO}_{2}$ analyzer. The light source (combined of three $250 \mathrm{~W}$ incandescent reflector lamps from above, through an $8 \mathrm{~cm}$ thick water screen, and of eight $20 \mathrm{~W}$ fluorescent lamps from two opposite sides of a photosynthetic chamber) gave quite uniform illumination, which was partially dispersed. Because of this type of light sources the total visible radiation could not be precisely determined but it was estimated as certainly exceeding $10,000 \mathrm{lux}$, i.e. about $35.000 \mathrm{erg} / \mathrm{cm}^{2} / \mathrm{sec}$. Air temperature inside the double-walled plexiglass chamber was maintained by an ultrathermostat at a constant level of $25^{\circ} \mathrm{C}$.

Determinations were carried out on excised current-year shoots since in preliminary experiments it had been proved that, in pine, there is no deviation in the rate of photosynthesis as compared with intact plants if the measurements are taken within a few minutes after detachement and the plant has previously been adapted to the given light conditions.

Dark respiration was measured on parallel shoots with a closed IRGA system and also on needle samples by means of the Warburg direct manometer technique. Samples for $\mathrm{O}_{2}$ uptake determinations consisted of 4-8 needles each, about 200 $\mathrm{mg}$ of fresh weight in all.

In experiments with the whole shoot, weight determinations were carried out at the moment of cutting and later at 10 minute intervals. It was found that during the circulation of air in a closed system $\left(\mathrm{Zn} \mathrm{Cl}_{2}\right.$ used as desiccator, $40 \mathrm{l} / \mathrm{h}$ flow rate of air $\cong 5 \mathrm{~mm} / \mathrm{sec}$ linear air speed in the chamber) the desiccation progresses linearly at least during the first 20 minutes. Hence, the initial water loss within. 10 minutes after cutting could be taken as a measure of transpiration.

The experiments were repeated 5 times at various stages of vegetation. However, it should be pointed out that since the conditions of measurement were always the same, the data represent the changes in plant capacity and not the actual rate of the processes occurring in the natural alternation of external conditions.

At every experiment parallel samples of needles were taken for spectrophotometric chlorophyll content analysis (Mackinney 1941; Bruinsma 1963), and 
for water saturation deficit determination (Claussen and Kozlowski 1965). About $500 \mathrm{mg}$ of fresh needles were taken as the average sample from several plants and after the determination of their saturation weight ( 24 hours in containers, needle base inserted in water) they were divided by half (by partition of the fascicles) one part being destined for dry matter determination and the other for chlorophyll analysis.

The number of replicates was 12 for photosynthesis measurement, 3 for dark respiration estimation of the whole shoot, 12 for manometric determinations of respiration on detached needles and 6 for chlorophyll and water saturation analysis; this number of parallel samples concerns each variant of soil moisture conditions on every date of sampling. After each experiment the plants used for determinations were harvested and the dry matter of needles, stems, and roots was established after drying the plant material at $105^{\circ} \mathrm{C}$.

\section{RESULTS}

After the first vegetation season the plants were not significantly differentiated in growth characteristics but some data indicated that watering to $60 \%$ of capillary capacity created the optimum conditions for dry matter production in the aerial

\section{Table 1}

Growth characteristics of seedlings cultivated under various soil water conditions, after the first vegetation season (aerial parts only, 96 replicates for each experimental variant)

\begin{tabular}{|c|c|c|c|}
\hline \multirow[b]{2}{*}{ Growth characteristics } & \multicolumn{3}{|c|}{ Soil moisture conditions } \\
\hline & $\begin{array}{c}40 \% \text { c.c. } \\
\text { (dry) }\end{array}$ & $\begin{array}{l}60 \% \text { c.c. } \\
\text { (moderate) }\end{array}$ & $\begin{array}{c}80 \% \text { c.c. } \\
\text { (wet) }\end{array}$ \\
\hline Needles & & & \\
\hline Number per plant & 108 & 112 & $107^{*}$ \\
\hline Dry matter of all needles (mg) & 215 & 230 & 198 \\
\hline Dry matter of a single needle $(\mathrm{mg})$ & 1,99 & 2,05 & 1,85 \\
\hline Lateral shoots & & & \\
\hline Number per plant & 2,22 & 2,33 & 1,84 \\
\hline Dry matter of all lateral shoots (mg) & 39 & 61 & 39 \\
\hline Average dry matter of one lateral shoot $(\mathrm{mg})$ & 1,76 & 2,62 & 2,12 \\
\hline Stem & & & \\
\hline length (mm) & 54 & 53 & 52 \\
\hline Dry matter of the whole stem (mg) & 45 & 53 & $43^{* *}$ \\
\hline Dry matter of $1 \mathrm{~mm}$ of the stem $(\mathrm{mg})$ & 0,83 & 0,99 & 0,83 \\
\hline Ratios: & & & \\
\hline Dry matter of the stem / dry matter of needles & 0,21 & 0,23 & 0,22 \\
\hline Dry matter of the stem/number of needles & 0,42 & 0,47 & 0,40 \\
\hline $\begin{array}{l}\text { Whole aerial part } \\
\text { Dry matter }(\mathrm{mg})\end{array}$ & 300 & 343 & 280 \\
\hline
\end{tabular}

* least significant deviation 4.3

$* *$ least significant deviation 3.5 
Table 2

Growth characteristics of seedlings after second vegetation season of cultivation under various soil moisture conditions ( 24 replicates for each experimental variant)

\begin{tabular}{|c|c|c|c|}
\hline \multirow{2}{*}{ Growth characteristics } & \multicolumn{3}{|c|}{ Soil moisture conditions } \\
\hline & $40 \%$ c.c. & $60 \%$ c.c. & $80 \%$ c.c. \\
\hline Needles & & & \\
\hline Number of needles on newly developed shoot* & 159 & 155 & 146 \\
\hline Dry matter of a single needle (mg) & & & \\
\hline mean from the whole shoot & 8,6 & 9,8 & 10,7 \\
\hline mean from the "top" needles only** & 15,6 & 17,7 & 19,5 \\
\hline Length ("top" needles only) $\mathrm{mm} * *$ & 87 & 88 & 94 \\
\hline Dry matter of all new needles $(\mathrm{g})$ & 1,37 & 1,52 & 1,56 \\
\hline $\begin{array}{l}\text { Dry matter of all needles (new }+ \text { oldspring juve- } \\
\text { nile needles***) }\end{array}$ & 1,64 & 1,89 & 1,92 \\
\hline Stem & & & \\
\hline Size (of new length increment) $\mathrm{mm}$ & 125 & 134 & 132 \\
\hline Dry matter of the new stem $(\mathrm{g})$ & 0,45 & 0,54 & 0,59 \\
\hline Dry matter of the whole stem $(\text { new }+ \text { old })^{* * *}$ & 0,74 & 0,95 & 0,98 \\
\hline Root & & & \\
\hline Dry matter of whole root-system (g) & 1,00 & 1,11 & 0,91 \\
\hline Dry matter of all aerial parts (shoot) $(\mathrm{g})$ & 2,38 & 2,84 & 2,90 \\
\hline Dry matter of whole plant $(\mathrm{g})$ & 3,38 & 3,95 & 3,80 \\
\hline Ratios: & & & \\
\hline Shoot/root & 2,5 & 2,7 & 3,3 \\
\hline stem/root & 0,8 & 0,9 & $1,1=$ \\
\hline Root + stem/needles & 1,1 & 1,1 & 1,0 \\
\hline $\begin{array}{l}\text { Dry matter of new stem/length of new stem } \\
(\mathrm{mg} / \mathrm{cm})\end{array}$ & 36 & 40 & 45 \\
\hline $\begin{array}{l}\text { Dry matter of one needle/length of needle } \\
(\mathrm{mg} / \mathrm{mm}) \text { ("top" needles only) }\end{array}$ & 1.8 & 2.0 & 2.1 \\
\hline
\end{tabular}

* Average from 60 replications (whole vegetation season).

** Data from experiments by Warburg technique.

$* *$ Lateral shoots included.

parts of seedlings. Although the height was, on the average, the same and the number of needles differed almost within the limits of error, other indices, including total dry matter of the aerial parts, showed the highest values at $60 \%$ of capillary capacity and the lowest in plants with excessive water supply (table 1).

During the second vegetation season the slight differences between the plants of "dry,, and "wet" treatments became even more evident especially towards the end of the growing season (table 2) though the proportions between the organs had changed to some extent. The number of needles formed on the new shoot was almost the same within the experimental variants with a slight tendency of decrease towards more humid conditions of growth, whereas the average weight of a needle significantly increased in "wet" culture. As a result the total dry matter of needles (per plant or per shoot) was lower in the plants of dry treatment and was almost 
equal at 60 or $80 \%$ of capillary capacity. The stem was also reduced in dry conditions of growth (both in length and in weight), but the root was reduced in two extreme treatments, being the largest in moderate treatment. The shoot/root and stem/root ratios increased from "dry" to "wet" treatments and the total dry matter of the whole plant was distinctly reduced at a moisture content of $40 \%$ of capillary capacity.

Determinations of relative turgidity of needles (Tables 3 ) did not show any significant difference between plants of different treatments. Only the seasonal change of this index is significant indicating a minimum value in full summer time. The water content in fresh weight of needles showed, as usual, a tendency to decrease towards the end of the vegetation season without any remarkable deflection in the particular variants.

Table 3

Water relations in needles of different experimental variants during the whole vegetation season

\begin{tabular}{|c|c|c|c|c|c|c|}
\hline \multirow[b]{2}{*}{ Characteristic } & \multirow{2}{*}{$\begin{array}{l}\text { Experi- } \\
\text { mental } \\
\text { variant }\end{array}$} & \multicolumn{5}{|c|}{ Date of determination } \\
\hline & & May 12 th & June 8th & July 17 th & $\begin{array}{l}\text { August } \\
29 \text { th }\end{array}$ & $\begin{array}{c}\text { October } \\
17 \text { th }\end{array}$ \\
\hline $\begin{array}{l}\text { Relative turgidity } \\
\text { (per cent) }\end{array}$ & $\begin{array}{l}40 \\
60 \\
80\end{array}$ & $\begin{array}{l}85,6 \\
87,3 \\
87,5\end{array}$ & $\begin{array}{l}90,8 \\
91,1 \\
90,7\end{array}$ & $\begin{array}{l}92,7 \\
93,5 \\
93,9\end{array}$ & $\begin{array}{l}88,6 \\
88,9 \\
88,6\end{array}$ & $\begin{array}{l}89,4 \\
89,8 \\
89,9\end{array}$ \\
\hline $\begin{array}{l}\text { Water content (per } \\
\text { cent of fresh } \\
\text { weight) }\end{array}$ & $\begin{array}{l}40 \\
60 \\
80\end{array}$ & $\begin{array}{l}77,1 \\
77,2 \\
77,9\end{array}$ & $\begin{array}{r}71,9 \\
71,2 \\
72,7\end{array}$ & $\begin{array}{l}70,3 \\
70,4 \\
69,4\end{array}$ & $\begin{array}{l}65,5 \\
67,6 \\
67,5\end{array}$ & $\begin{array}{l}66,0 \\
67,2 \\
67,5\end{array}$ \\
\hline
\end{tabular}

No significant difference was found between the experimental variants in the rate of net photosynthesis expressed per $1 \mathrm{~g}$ of dry weight of needles (fig. 1). Only at the beginning of the vegetation season, in mid May, a regularity could be observed that plants cultivated at a lower soil moisture level show higher photosynthesis rates than those grown with a higher water supply. Seasonal changes of the photosynthesis rate were generally the same as in our previous studies (Żelawski and Góral 1966; Żelawski and Kinelska 1967).

Photosynthetic activity expressed per number of assimilatory organs showed higher values in seedlings cultivated at higher water supply than in those of the dry treatment; this is certainly due to the different sizes of needles, as the rate of photosynthesis expressed per dry weight is very much the same. The maximum value of photosynthetic activity occurred in late summer, when needles were already fully developed, and the winter depression did not yet interfere.

The prolonged growth of needles in plants with excess of water in the soil probably brought about some differences in the winter depression advance which can be seen from the data on photosynthesis rates and photosynthetic activities, in fig. 1 .

Assimilation numbers given in the same fig. 1 are least reliable since they were calculated from chlorophyll data obtained on parallel, but not the same and not 
so abundant samples as those used for photosynthesis determination. This caused some variability which excludes full comparison of the experimental variants. However, it seems evident that after formation of new assimilatory organs the "normally" watered plants, having higher chlorophyll $(a+b)$ concentrations (tab. 4), exhibit the lowest assimilation numbers, as compared with the "dry" and "wet" variants of the experiment.

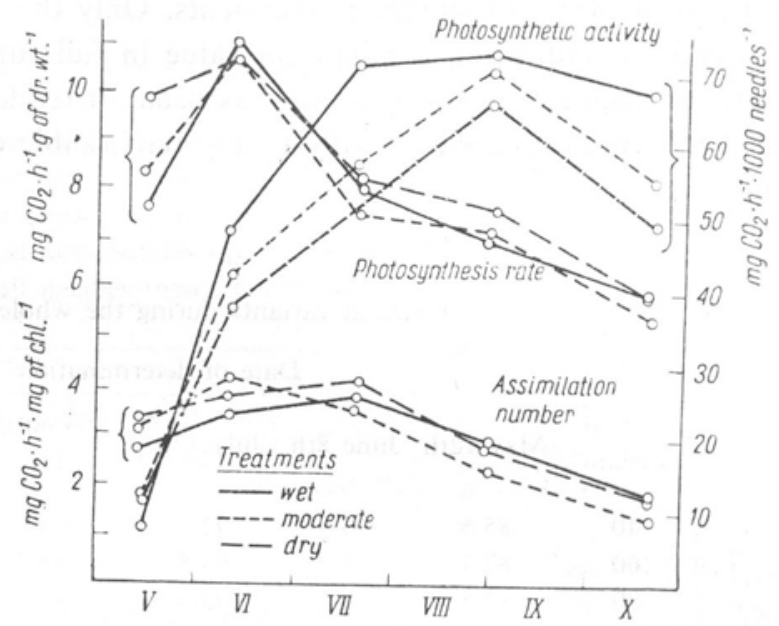

Fig. 1. Seasonal changes of net photosynthesis in seedlings of different soil moisture pretreatment

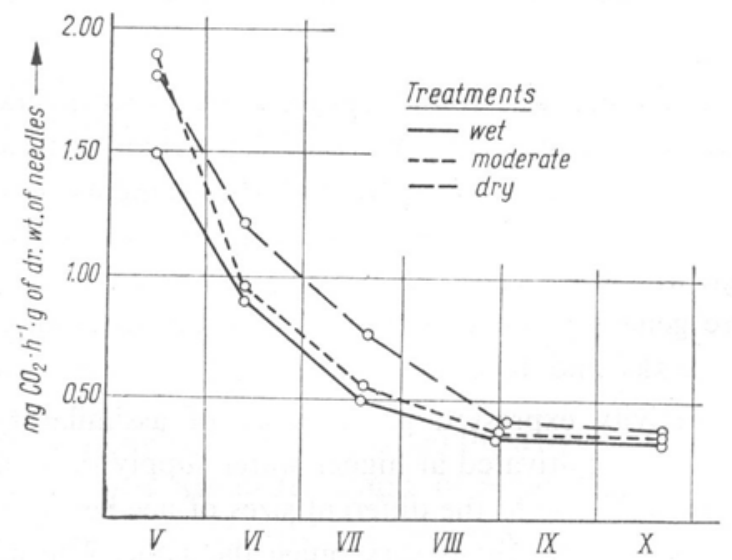

Fig. 2. Seasonal changes of dark respiration in plants of different treatment

The respiration rate calculated per dry matter of needles from IRGA-determinations shows in all experiments and throughout the whole vegetation season that in pines growing under limited water supply the intensity of the process is the highest (fig. 2). The same regularity is seen from the average data of Warburgdeterminations (tabl. 5) what indicates that incresaed respiration of "dry" plants is also the case in detached needles. 
Table 4

Chlorophyll $(a+b)$ content and ratio chl. $a /$ chl. $b$ in needles of different experimental variants during the whole vegetation season

\begin{tabular}{|c|c|c|c|c|c|c|}
\hline \multirow{2}{*}{ Characteristic } & \multirow{2}{*}{$\begin{array}{c}\text { Experi- } \\
\text { mental } \\
\text { variant } \\
\text { c.c. }\end{array}$} & \multicolumn{5}{|c|}{ Date of determination } \\
\hline & & May 12 th & June 8th & July 17 th & August 29th & October 17 th \\
\hline \multirow{3}{*}{$\begin{array}{l}\text { Chlorophyll }(a+b) \\
\text { per } 1 \mathrm{~g} \text { of dry } \\
\text { weight of needles } \\
(\mathrm{mg})\end{array}$} & 40 & 2,9 & 2,8 & 2,0 & 2,8 & 3,4 \\
\hline & 60 & 2,6 & 2,6 & 2,2 & 3,0 & 3,8 \\
\hline & 80 & 2,8 & 3,2 & 2,1 & 2,4 & 3,3 \\
\hline \multirow{3}{*}{$\begin{array}{l}\text { Chlorophyll }(a+b) \\
\text { per } 1 \text { needle }(\mathrm{mg})\end{array}$} & 40 & 3 & 12 & 13 & 23 & 26 \\
\hline & 60 & 4 & 14 & 17 & 25 & 32 \\
\hline & 80 & 4 & 18 & 20 & 25 & 29 \\
\hline \multirow[t]{3}{*}{ Ratio $a / b$} & 40 & 2,4 & 2,5 & 2,2 & 2,4 & 2,4 \\
\hline & 60 & 2,5 & 2,4 & 2,3 & 2,4 & 2,7 \\
\hline & 80 & 2,6 & 2,5 & 2,3 & 2,4 & 2,4 \\
\hline
\end{tabular}

Table 5

Average dark respiration rates as measured by manometer technique for pine needles in seedlings grown at different water stress pretreatment (mean data from 6 experiments during summer time, 12 replications in each experiment)

\begin{tabular}{|c|c|c|c|c|}
\hline \multirow{2}{*}{$\begin{array}{c}\text { Soil moisture } \\
\text { conditions } \\
\text { during culture }\end{array}$} & $\begin{array}{c}|c| \\
\text { per 1 g of } \\
\text { dry weight }\end{array}$ & $\begin{array}{c}\text { per 1 g of fresh } \\
\text { weight }\end{array}$ & $\begin{array}{c}\text { per single } \\
\text { needle }\end{array}$ & $\begin{array}{c}\text { per 1 dm of } \\
\text { needle length }\end{array}$ \\
\hline $40 \%$ & 687 & 246 & 9.5 & 12.3 \\
$60 \%$ & 648 & 236 & 9.9 & 12.2 \\
$80 \%$ & 637 & 225 & 10.6 & 12.2 \\
\hline
\end{tabular}

The respiration rates expressed per one needle exhibit no great difference between experimental variants what results from an opposite trend in the change of needle size and the respiration rate. Yet, the rates of respiration calculated per $1 \mathrm{dm}$ of needle length are very much the same. The differences in respiration rates at the same level of photosynthesis gave a distinct difference between the "wet" and "dry" treatments in the index of $(\mathrm{A}+\mathrm{R}) / \mathrm{R}$ (true photosynthesis: dark respiration). During the whole vegetation season (with the exception of the first experiment) the plants of the "dry" treatment always showed lower values of the $(\mathrm{A}+\mathrm{R}) / \mathrm{R}$ ratio than plants oversupplied with water; normally watered plants were intermediate in this respect (fig. 3). 


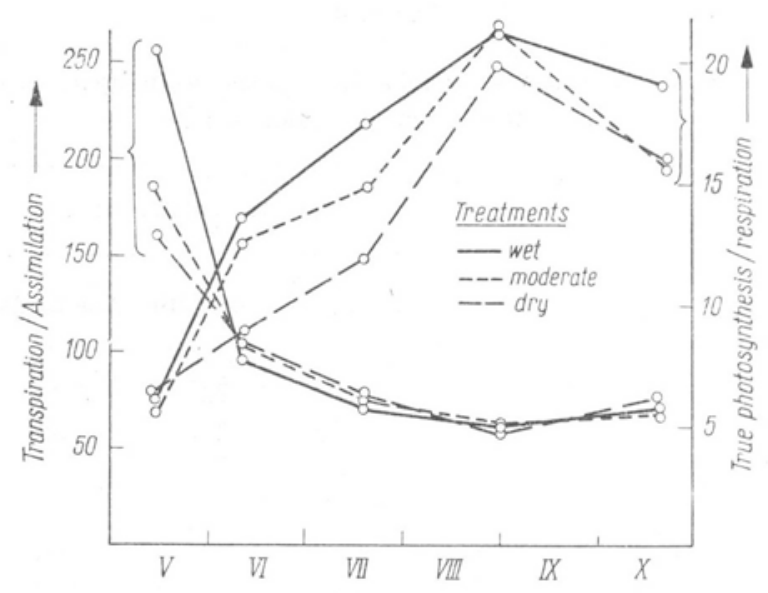

Fig. 3. Transpiration/Assimilation and True photosynthesis/dark respiration in plants of different soil moisture pretreatments

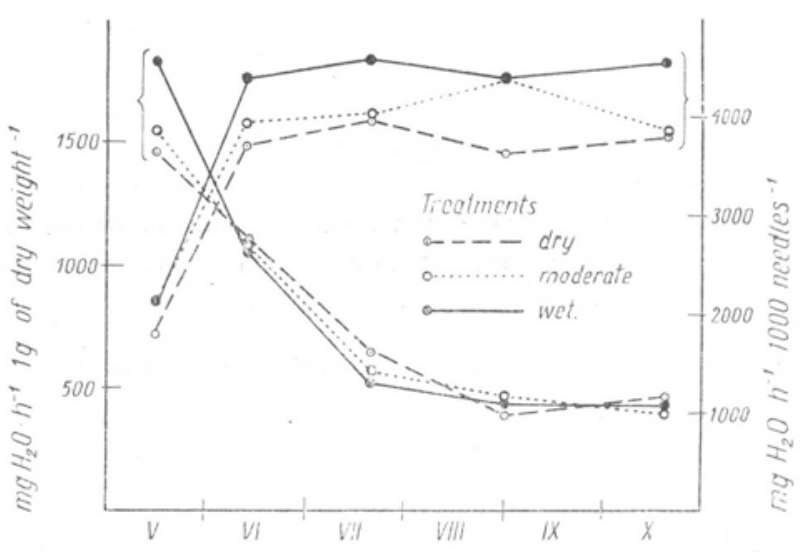

Fig. 4. Seasonal changes of transpiration rate in plants cultivated at different soil moisture conditions

The ratio: transpiration to net photosynthesis, on the other hand, differed significantly only during the first experiment (at the beginning of shoot growth) and the difference disappeared later when transpiration considerably decreased during the vegetation season. The transpiration rate was different between the treatments at early stages of vegetation (fig. 4). The data certainly indicate that the T/A ratio, much higher in "wet" than in "dry" plants (at the beginning of shoot growth), is due to both higher transpiration rates and lower photosynthesis rates in this experimental variant. It is worth stressing that the transpiration "capacity" calculated as the transpiration rate per 1000 needles does not vary much during the summer and autumn months, since the decrease of the rate per $1 \mathrm{~g}$ of dry matter is compensated by simultaneous growth of the needles; hence, the total water loss 
of the shoot may be expected to be nearly constant over the whole vegetation season and only controlled by actual environmental conditions. Because of difference in needle size in plants of different water stress pretreatments, it is obvious that also differences in transpiration of 1000 needles are clear as was the case with photosynthetic activity.

\section{DISCUSSION}

The effect of water stress on physiological processes in plants was extensively studied usually by measuring the changes which occur either in conditions of continuously deteriorating water balance when water supply had been suddenly checked or under temporary exposure to dry conditions. For coniferous trees the following papers greatly contributed to elucidation of questions concerning drought tolerance as well as cessation and recovery of physiological activity under transient influence of water stress: Sands and Rutter (1959), Polster and Fuchs (1960), Clark (1961), Brix (1962), Tranquillini (1963), Jarvis and Jarvis (1963), Negisi (1966), Lister and coworkers (1967), and others.

Yet, the effect of long-term water stress pretreatment although related, to some extent, to drought tolerance of plants is not directly comparable with the reactions to drastic disturbance of the water balance and concerns rather the phenomena of adaptability. Plants grown under favourable conditions and then treated with drought or water excess exhibit only an ability to survive determined by the structural and physiological properties established before. Growing, however, continuously at lower or higher soil moisture availability they adapt themselves to the given conditions by an alternative formation of their vegetative organs and by development of such physiological properties which would help to withstand the unfavourable influences.

From this point of view experiments of Simonis (1952) are of great interest, although they only concern herbaceous plants. In this extensive study the superiority in photosynthetic ability of plants adapted to dry conditions, has been clearly demonstrated, while on the other hand no clear picture was obtained concerning the rate of respiration. These findings did not fully agree with the earlier state of knowledge: other authors often reported that in plants grown in dry conditions the respiration rate is lower. Our results confirm the finding of Simonis only as far as the increased photosynthesis rates of young developing needles is concerned; mature needles from plants of different water regimes did not show any significant difference. On the other hand the experiments showed most intensive respiration rate in "dry" plants what was not always the case in Simonis'work. As various plants may behave differently when exposed to prolonged dry treatment, further research in the field of adaptability seems to be desirable.

Although our soil moisture levels did not differ very widely and the plants experienced only a slight influence of increased soil moisture tension (up to about $2 \mathrm{pF}$ ) some signs of adaptation to drought are already noticeable in the varying development of particular organs. The ratios: shoot/root and stem/root, and dry matter 
content calculated per $1 \mathrm{~mm}$ of needle length or per $1 \mathrm{~cm}$ of stem length clearly indicate that the more water is available in the soil, the more organic production remains in the upper parts of the plant. The total dry matter production of the whole plant as well as the weight of the root system and height of the new increment were, in our experiment, the highest in plants under moderate watering, but the proportions of the organs show that water stress may influence the distribution and translocation of the photosynthesis products. There are no data available which would directly support the claim as to the stimulating effect of permanent drought on translocation. Lister et al. (1967) who investigated the translocation of ${ }^{14} \mathrm{C}$-labelled products from needles to roots in white pine seedlings grown at two levels of water supply did not obtain any convincing result in this respect. However, the increased respiration rate in the whole shoot, observed in our plants under dry treatment during most of the vegetation season, might be considered as an indirect proof of the increased activity of conducting elements in needles and stems. If one assumes that plants growing continuously under unfavourable soil moisture tension are "forced" to transport a great deal of their photosynthetic products to maintain a high activity of their root system, it becomes very probable that such transport must be accompanied by higher respiration rates what finally brings about some shortage of materials for further growth of needles. It is very symptomatic that Lister et al. (1967) did not find any difference in the respiration rate of plants of "dry" and "wet" treatment, and the shoot/root ratio also showed an opposite trend in their experiments as compared with ours.

A reduction of the total weight or length of needles has also been found in the investigations of Sands and Rutter (1959), Rutter (1967), and Lister et al. (1967). It must play an important role in the water economy of plants. Indeed, some authors reported an increase of the T/A ratio with deteriorating soil water potential. Jarvis and Jarvis (1963) found in Scots pine an almost linear relationship between soil water content and the $\mathrm{T} / \mathrm{A}$ index calculated from the average daily sum of transpiration and simultaneous dry matter increase. Larcher (1965) also showed a greater reduction of water consumption than of the dry weight increment in some woody plants exposed to drought. In the investigations of Lister et al. (1967) there was significant reduction of transpiration in plants grown at a low moisture level without any depletion of the photosynthesis rate. In our experiment the direct adaptation of plants to carry on intensive photosynthesis at relatively low water loss could only be confirmed for the earliest stages of development; during the later period of vegetation the ratio T/A (water loss: $\mathrm{CO}_{2}$ uptake) as well as photosynthesis and transpiration rates alone were very much the same for all experimental variants. However, the high photosynthesis rates found at the beginning of the vegetation season can be interpreted as the same effect as that observed by Tranquillini (1963) in plants grown (for two months) under various soil water content conditions and examined at different air humidity.

The data presented clearly indicate that in Scots pine seedlings there is no direct correlation between either the photosynthesis rate or the assimilation number and the total dry matter production of the plant adapted to different soil 
moisture conditions. The seasonal course of photosynthesis rate was very much the same in plants of different treatment, this incidentally being in agreement with the finding of Lister et al. (1967), but the highest dry matter production was obtained at moderate water supply. (Some reciprocal reaction of "wet" plants during both vegetation seasons may be attributed to various effects of wheather conditions or to the incomparability of juvenile and second year stages of vegetation). The photosynthetic activity expressed in respect to needle number and the ratio $(\mathrm{A}+\mathrm{R}) / \mathrm{R}$ increased with improvement of the water supply, but the total dry matter production was not proportional to these values. Only the suppression of growth in dry conditions can be interpreted in terms of a limited photosynthetic ability while the total production of dry matter in plants of the "wet" treatment in comparison with the moderate one did not parallel the results of photosynthesis and respiration measurements. It is obvious that in photosynthetic productivity of a plant, not only the potential ability of its assimilatory organs is involved, but also the ability to withstand the natural fluctuations of environmental influences. Perhaps plants growing in "wet" soil become more sensitive to such fluctuations and despite of their high photosynthetic ability in laboratory conditions, they are not able to produce much when they are growing out-of-doors. Such increased sensitivity of plants grown at higher water supply was reported by Tranquillini (1963).

This may be connected with relatively poor development of the root system found in our research as well as in Tranquillini's (1966) work (but not by Jarvis and Jarvis 1963 or Lister et al. 1967 probably because of the transplantation procedure they applied for two-year-old pines). Our determinations of water saturation deficit were always carried out in the morning and they did not show any noticeable difference between the plants of various water stress pretreatments. As the $\mathrm{CO}_{2}$ diffusion into the mesophyll cells is largely controlled by the internal water balance of a leaf, it is understandable that very much the same photosynthesis rates were obtained in plants on different soil water regimes when studied under laboratory conditions. However, a diurnal change of this situation might be suspected, and consequently it could also influence the total photosynthetic production of plants grown with some excess of water in the soil.

The results of our work did not confirm the thesis of Rutter (1966) that the leaf number of Scots pine is reduced by drought. More probable is the influence of drought on needle differentiation at the time of bud formation (Clements 1964). However, in our experiments, plants of the second year of growth only slightly differed as regards this feature showing rather opposite trends, i.e. the reduction of needle number in "wet" culture conditions.

Unfortunately the experiments presented did not give any further contribution to the question of provenance testing. Perhaps the differences in the reaction of plants of various origin are, if any, not discernible within such a narrow range of soil moisture conditions. Also the number of replicates should be probably much higher than, it could be achieved in this stage of study owing to technical difficulties. 


\section{SUMMARY}

The problem of the effect of different soil moisture conditions on growth and photosynthetic productivity of Scots pine seedlings is discussed. The physiological processes were studied on plants grown continuously under different water regimes and the results of the investigation concern rather the problem of adaptability than drastic water stress disturbances. Experiments gave several results which may help to explain the causes of different productivity of pine growing under different conditions of water stress pretreatment. Increased respiration rate in plants suffering permanent drought, adaptation of assimilatory organs to limit the water loss at least at early stages of vegetation, different proportions of needles, root, and stems in plants of various water regimes are the main facts established in this research.

Department of Forestry

(Entered: July 20, 1968.)

Warsaw Agricultural University

\section{REFERENCES}

Brix H., 1962, The effect of water stress on the rates of photosynthesis and respiration in tomato plants and loblolly pine seedlings, Physiol. Plant 15: 10-20.

Bruinsma J., 1963, The quantitative analysis of chlorophyll a and b in plant extracts, Photochem. Photobiol. 2: 241-249.

Clark J., 1961, Photosynthesis and respiration in white spruce and balsam fir., State University, College of Forestry Syracuse, New York: 1-72.

Claussen J. J., Kozlowski T. T., 1965, Use of the relative turgidity technique for measurements of water stresses in gymnosperm leaves, Canad. J. Bot. 43: 305-317.

Clements J. R., 1964, Growth response of red pine seedlings to fall and spring water supply, Bull. Ecol. Soc. Amer. 45: 150.

Jarvis P. G., Jarvis M. S., 1963, The water relations of tree seedlings I. Growth and water use in relation to soil water potential, Physiol. Plant. 16: 215-235.

Kozlowski T., Keller T., 1966, Food relations of woody plants, The Bot. Rev. 32: 293-382.

Larcher W., 1965, The influence of water stress on the relationship between $\mathrm{CO}_{2}$ uptake and transpiration, Symposium: Water stress in plants, Czechoslovak Academy of Sciences: 184-193.

Lister G. R., Slankis V., Krotkov G., Nelson C. D., 1967, Physiology of Pinus strobus L., seedlings grown under high or low soil moisture conditions. Ann. of Bot. 31: 121-132.

Mackinney G., 1941, Absorption of light by chlorophyll solutions, J. biol. Chem. 140: 315-322. Negisi K., 1966, Photosynthesis, respiration and growth in 1-year-old seedlings of Pinus densiflora, Cryptomeria japonica and Chamaecyparis obtusa, Tokyo University Forests 62: 1-115. Pisek A., 1960, Immergrüne Pflanzen (einschlieslich Coniferen, Encycl. of Pl. Physiol. V/2 Ed. by W. Ruhland: $415-459$.

Polster H., Fuchs S., 1960, Der Einfluss intermittierender Belichtung auf die Transpiration und Assimilation von Fichte und Lärche bei Dürrebelastung, Biol. Zentralblatt 79: 465-479.

Rutter A. J., 1966, Water relations and growth in trees, Forestry Supplement, University Press, Oxford, England :19-31.

Rutter A. J., 1967, Studies of the water relations of Pinus sylvestris in plantation conditions. V. Responses to variation in soil water conditions, J. Appl. Ecol. 4: 73-81.

Sands K., Rutter A. J., 1959, Studies in the growth of young plants of Pinus sylvestris L. II. The relation of growth to soil moisture tension, Ann. of Bot. N. S. 23: 269-284.

Simonis W., 1952, Untersuchungen zum Dürreeffeckt, I. Morphologische Struktur, Wassergehalt, Atmung und Photosynthese feucht und trocken gezogener Pflanzen. Planta 40: 313-332. Stocker O., 1956, Die Dürreresistenz, Encycl. of Pl. Phys. 3 Ed. by W. Ruhland: 696 -741.

Tranquillini W., 1963, Die Abhängigkeit der Kohlen-Säureassimilation junger Lärchen, Fichfen 
und Zirben von der Luft- und Boden feuchte. Versuche in einem klimatisierten Windkanal. Planta 60 (70-94).

Żelawski S., Góral I., 1966, Seasonal changes in the photosynthesis rate of Scots pine (Pinus silvestris L.) seedlings grown from seed of various provenances, Acta Soc. Bot. Pol. 35: 587598.

Żelawski W., Kinelska J., 1967, Photosynthesis and respiration of Scots pine (Pinus silvestris L.) seedlings of various provenances grown under different light conditions, Acta Soc. Bot. Pol. 36: 713-723.

Żelawski W., Kinelska J., Łotocki A., 1968, Influence of shade on productivity of photosynthesis in seedlings of Scots pine (Pinus silvestris L.) during the second vegetation period, Acta Soc. Bot. Pol. 37: 505-518.

Produktywność fotosyntezy u siewek sosny zwyczajnej (Pinus silvestris L.) wyhodowanych $w$ różnych warunkach wilgotności gleby

\section{Streszczenie}

Badano wpływ stałych warunków wilgotności gleby na wzrost, akumulację suchej masy i intensywność fotosyntezy, oddychania i transpiracji u siewek sosny w drugim okresie wegetacji. Usiłowano stwierdzić na czym polega i w czym się przejawia zdolność adaptacyjna tego gatunku, kiedy rośliny znajdują się od pierwszych dni wegetacji pod działaniem określonego układu stosunków wodnych. Zagadnienie wydaje się istotne ze względu na to, że większość badań przeprowadzonych w aspekcie ,,wilgotność gleby a procesy fizjologiczne", dotyczy reakcji rośliny na okresowe zakłócenia bilansu wodnego, natomiast prace poświęcone wpływom długotrwałego oddziaływania niedoboru lub nadmiaru wody w glebie są nieliczne.

Wyniki badań potwierdzają istnienie u sosny dużej zdolności przystosowawczej, co wyraża się utrzymywaniem podobnego poziomu intensywności fotosyntezy u roślin rosnących w różnych warunkach wilgotności gleby. Stwierdzono jednak, że w warunkach słabego niedoboru wody intensywność oddychania roślin, w ciągu całego okresu wegetacji jest wyższa, a u młodych rozwijających się pędów obserwuje się mniejszą intensywność transpiracji i niższą wartość stosunku T/A. Ponadto zróżnicowanie wilgotności gleby wpływa w pewnym stopniu na całkowitą produkcję suchej masy roślin, przy czym najbardziej charakterystyczne są różnice rozmieszczenia tej masy w obrębie poszczególnych organów rośliny. Wydaje się, że warunki stałego niedoboru wody w glebie powodują pewien niedorozwój części nadziemnej rośliny (głównie zmniejszenie wymiarów organów asymilacyjnych), podczas gdy zaopatrzenie w wodę powyżej optymalnego poziomu odbija się przede wszystkim na kształtowaniu systemu korzeniowego. W wyniku tego obserwuje się w miarę zwięks zania zawartości wody w glebie, wyraźny wzrost stosunku masy części nadziemnej i korzenia $(\mathrm{S} / \mathrm{R})$. 